\title{
Regulation and dysregulation of immunoglobulin E: a molecular and clinical perspective
}

Mariah B Pate ${ }^{1}$, John Kelly Smith ${ }^{1,2}$, David S Chi ${ }^{2}$, Guha Krishnaswamy ${ }^{1,2,3^{*}}$

\begin{abstract}
Background: Altered levels of Immunoglobulin E (IgE) represent a dysregulation of IgE synthesis and may be seen in a variety of immunological disorders. The object of this review is to summarize the historical and molecular aspects of IgE synthesis and the disorders associated with dysregulation of IgE production.

Methods: Articles published in Medline/PubMed were searched with the keyword Immunoglobulin E and specific terms such as class switch recombination, deficiency and/or specific disease conditions (atopy, neoplasia, renal disease, myeloma, etc.). The selected papers included reviews, case reports, retrospective reviews and molecular mechanisms. Studies involving both sexes and all ages were included in the analysis.
\end{abstract}

Results: Both very low and elevated levels of IgE may be seen in clinical practice. Major advancements have been made in our understanding of the molecular basis of IgE class switching including roles for $T$ cells, cytokines and $T$ regulatory (or Treg) cells in this process. Dysregulation of this process may result in either elevated lgE levels or IgE deficiency.

Conclusion: Evaluation of a patient with elevated IgE must involve a detailed differential diagnosis and consideration of various immunological and non-immunological disorders. The use of appropriate tests will allow the correct diagnosis to be made. This can often assist in the development of tailored treatments.

\section{Introduction}

Immunoglobulin E has traditionally been associated with atopic disease and systemic anaphylaxis. However, its role in host defense, parasitic infection and immune surveillance suggest many other potential functions. The initial description of anaphylaxis was made by Portier and Richet in 1902 which led to Richet receiving the Nobel Prize for medicine in 1913 (Figure 1A). The mast cell was first described by Paul Ehrlich while experimenting with Aniline dyes as a medical student in 1878 (Figure 1B and 1C); he was awarded the Nobel Prize for his therapeutic discoveries in Medicine in 1908. The discovery of IgE by the Ishizakas (Figure 1D) in 1966 was a major advancement. Further understanding of IgE immunobiology was made possible by the description of class switch recombination (discussed later) by Susumu Tonegawa (Figure 1E), a Japanese scientist working in the United States. For this, he was awarded the Nobel Prize in Medicine in 1985.

\footnotetext{
* Correspondence: krishnas@etsu.edu

'Division of Allergy and Immunology, Quillen College of Medicine, East Tennessee State University, Johnson City, TN 37614, USA
}

\section{Molecular Regulation of IGE Production}

Immunoglobulin $\mathrm{E}$ is a class of immunoglobulin essential for the allergic response (Figure 1F). IgE is formed by the B lymphocyte and after several gene rearrangement steps is secreted. The production of IgE is regulated by genes, cytokines and the environment (Figure 2).

Immunoglobulin $\mathrm{E}$ consists of two identical heavy chains and two identical light chains with variable (V) and constant $(\mathrm{C})$ regions (Figure 1F). The $\varepsilon$-heavy chains contain one variable heavy chain and four constant region domains (CE 1-4). Immunoglobulin domains each contain around 110 amino acids and are beta sheets with three and four beta strands in the $C$ type topology [1]. IgE is a component of a network of proteins involved in the signaling response to an allergen/antigen. These proteins include FceRI, the high affinity receptor for IgE, CD23 (also known as FceRII), the low affinity receptor for IgE, and galactin-3, the $\operatorname{IgE}$ and FceRI binding protein. The known physiological properties of IgE are summarized in Table 1. Binding of IgE to FceRI on mast cells and basophils induces signaling and leads to mast cell degranulation and mediator release. 


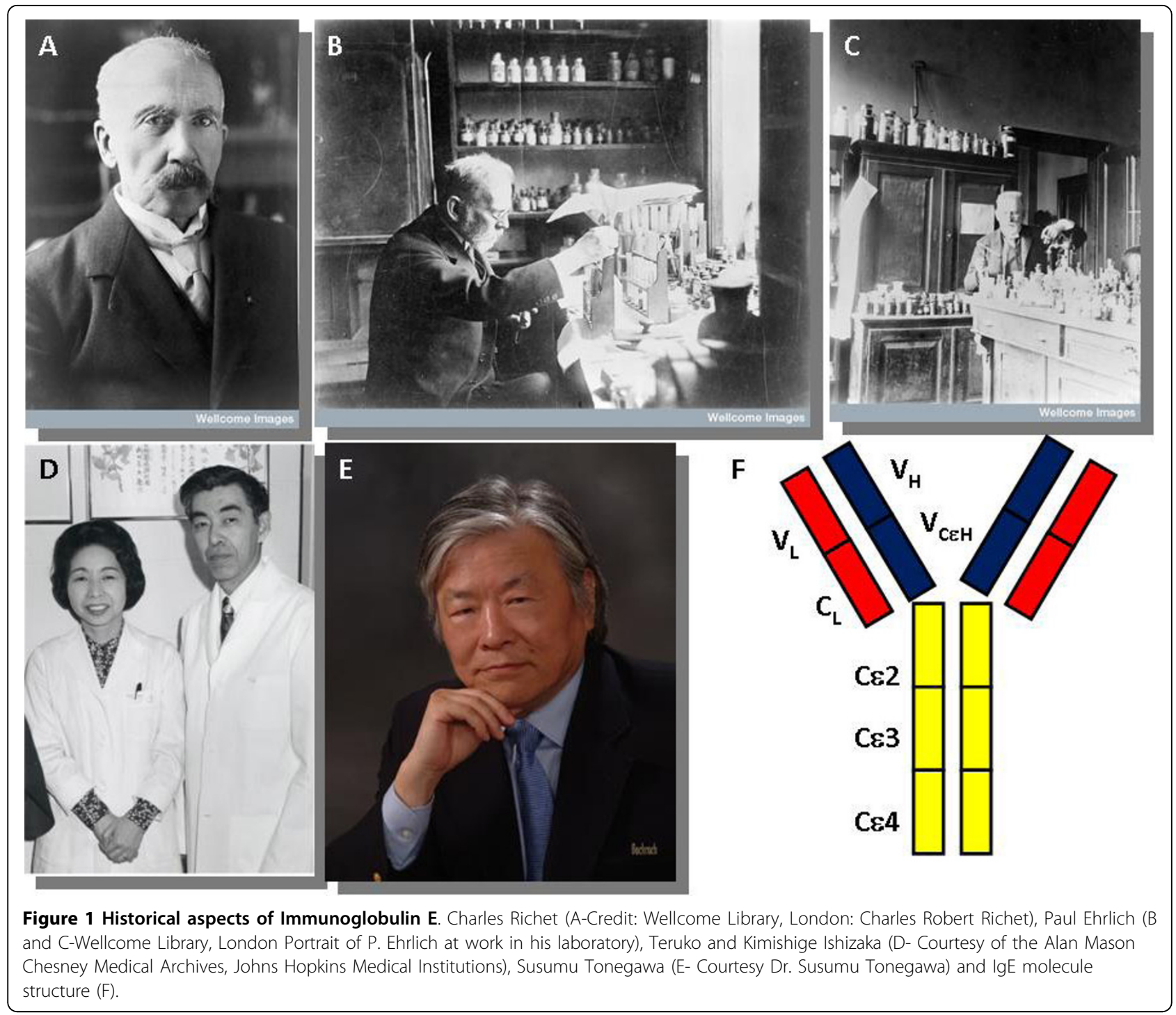

These include proteases, lipid mediators, and a plethora of cytokines, chemokines and growth factors. These mediators are partially responsible for eosinophil activation and survival seen in many disorders associated with elevated IgE [2-6].

\section{Cell-Cell Interactions in IgE Synthesis}

In the accepted model, an antigen/allergen is presented by a B cell, in the context of MHC class II molecules, to a Th2 cell, which recognizes the antigen via its $T$ cell receptor (TcR)/CD3 complex. This leads to the expression of CD154 (or CD40 ligand) on the $\mathrm{T}$ cell, which engages the counter-receptor, CD40, to be expressed on B cells. This engagement of TcR/CD3, MHC II, antigen/ peptide, CD154 and CD40 at the "immune synapse" leads to a sequence of events culminating in IgE secretion by the B cell (Figure 3 ). The sequential events include induction of $\mathrm{CD} 80 / 86$ on the $\mathrm{B}$ cell that engages CD28 on the $\mathrm{T}$ cell, leading to transcription of pivotal Th2 cytokines IL-4 and/or IL-13. Following secretion, these cytokines bind to corresponding receptors (IL-13R or IL-4R) on the B cell, leading to STAT6 activation in B cells. This synergizes with Nf- $\kappa \mathrm{B}$, activated via switch receptors (CD40 and others), to induce activation-induced cytosine deaminase (AID) which induces class switch recombination (Figure 3) and activates germline transcription of $\mathrm{C} \varepsilon$.

\section{IgE Class-Switch Recombination}

A two-step process of DNA excision and ligation are required for assembly of a functional IgE. In the primary response, characterized by expression of membrane IgM and IgD, VDJ (heavy chain) and VJ (light chain) recombination occurs in fetal tissue (liver and bone marrow). 


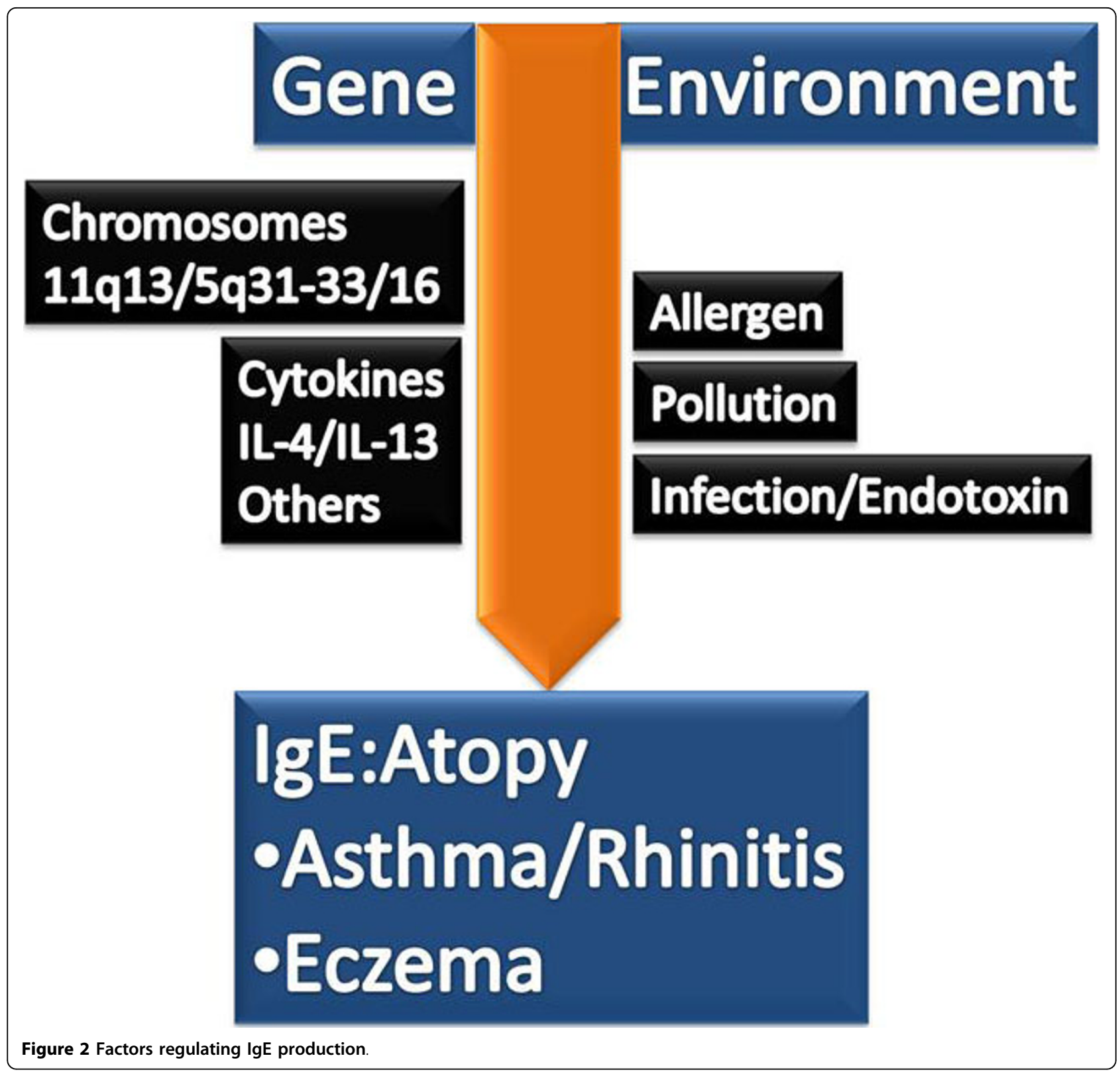

This is both an antigen and a $\mathrm{T}$ cell-independent process. In the secondary immune response, which results in formation of the isotypes IgG, IgA and IgE, class switch recombination (CSR) occurs in secondary lymphoid tissues (lymphoid tissue, spleen and tonsils). This is $\mathrm{T}$ cell/cytokine dependent and an antigen dependent process. This results in high affinity antibodies, further modified by the process of somatic hypermutation (SHM). SHM results from missense mutations in the $\mathrm{V}$ regions of the immunoglobulin molecule.

First, during the pre-B cell stage, the individual heavy chain variable $\left(\mathrm{V}_{\mathrm{H}}\right)$, diversity $(\mathrm{D})$ and joining $\left(\mathrm{J}_{\mathrm{H}}\right)$ exons randomly combined to form a $\mathrm{V}_{\mathrm{H}}(\mathrm{D}) \mathrm{J}_{\mathrm{H}}$ cassette that encodes an antigen-specific $\mathrm{V}_{\mathrm{H}}$ domain. This cassette is upstream of the constant $\mu$ exons and allows for the assembly of complete VDJ exons that encode an antigen-binding $\mathrm{V}_{\mathrm{H}}$ domain which produces intact $\mu$ heavy chains. The second step, class-switch recombination, is required for mature $B$ cells to alter the isotope of their antibodies, while retaining their antigen specificity. This involves tightly regulated and irreversible exchange of the various isotope's VHJ cassette to construct different heavy chains [7]. The Ce locus of IgE is similar to other $\mathrm{C}_{\mathrm{H}}$ loci. The 5 ' region of each heavy chain isotope gene includes switch regions with tandem repeats, known as S $\varepsilon$ and $\mu$. In CSR, two switch regions, $S \varepsilon$ and $\mu$ are combined, which allows the joining of the $\mathrm{V}_{\mathrm{H}}(\mathrm{D}) \mathrm{J}_{\mathrm{H}}$ and $\mathrm{C} \varepsilon$ regions. This joining generates a functional gene 
Table 1 The Physiological Properties of Immunoglobulin E

\begin{tabular}{ll}
\hline General Characteristics & Molecular weight: 190,000 Da (170 kDa protein; $20 \mathrm{kDa}$ Carbohydrate) \\
& Type: Monomer \\
& Subclasses: None \\
\hline Biology & Does not fix complement \\
& Does not cross the placental barrier \\
& Half-life: 2 days \\
& Isoforms: Secreted and membrane bound IgE \\
& Structure: Two light chains ( $\kappa$ or $\lambda$ ) and 2 heavy chains $(\varepsilon)$ \\
\hline Function & Binds to High affinity lgE receptor (FcERI) and degranulates mast cells and basophils \\
& Immediate Hypersensitivity \\
& IgE-mediated antigen presentation via FcERI \\
\hline
\end{tabular}

encoding IgE. CSR leading to IgE production is induced by cytokines IL-4 or IL-13 secreted by T helper 2 (TH2) cells [8].

The Role of T cells, Cytokines and Tregs

Several $\mathrm{T}$ cell derived cytokines play a pivotal role in IgE CSR and expression (Figure 4). The cytokines that induce IgE CSR and/or IgE production in humans include: IL-4 and IL-13 (essential for CSR), TSLP (increases IL-4 and
IL-13), IL-18 (increases IL-4 and IL-13 in some systems), IL-25 (increases IL-4 and IL-13) and IL-33 (increases IL-4 and IL-13). The authors showed that polymorphisms in chromosome 5q31.1 (Th2 cytokine cluster including IL-4 gene) were associated with IgE levels using sib-pair analysis [9]. The following cytokines inhibit IgE CSR and/ or production: IFN $\gamma$, IL-10, IFN $\alpha$ and $\beta$ (inhibit IgE production and also inhibit Th2 cytokine generation), TGF $\beta$ and IL-21.

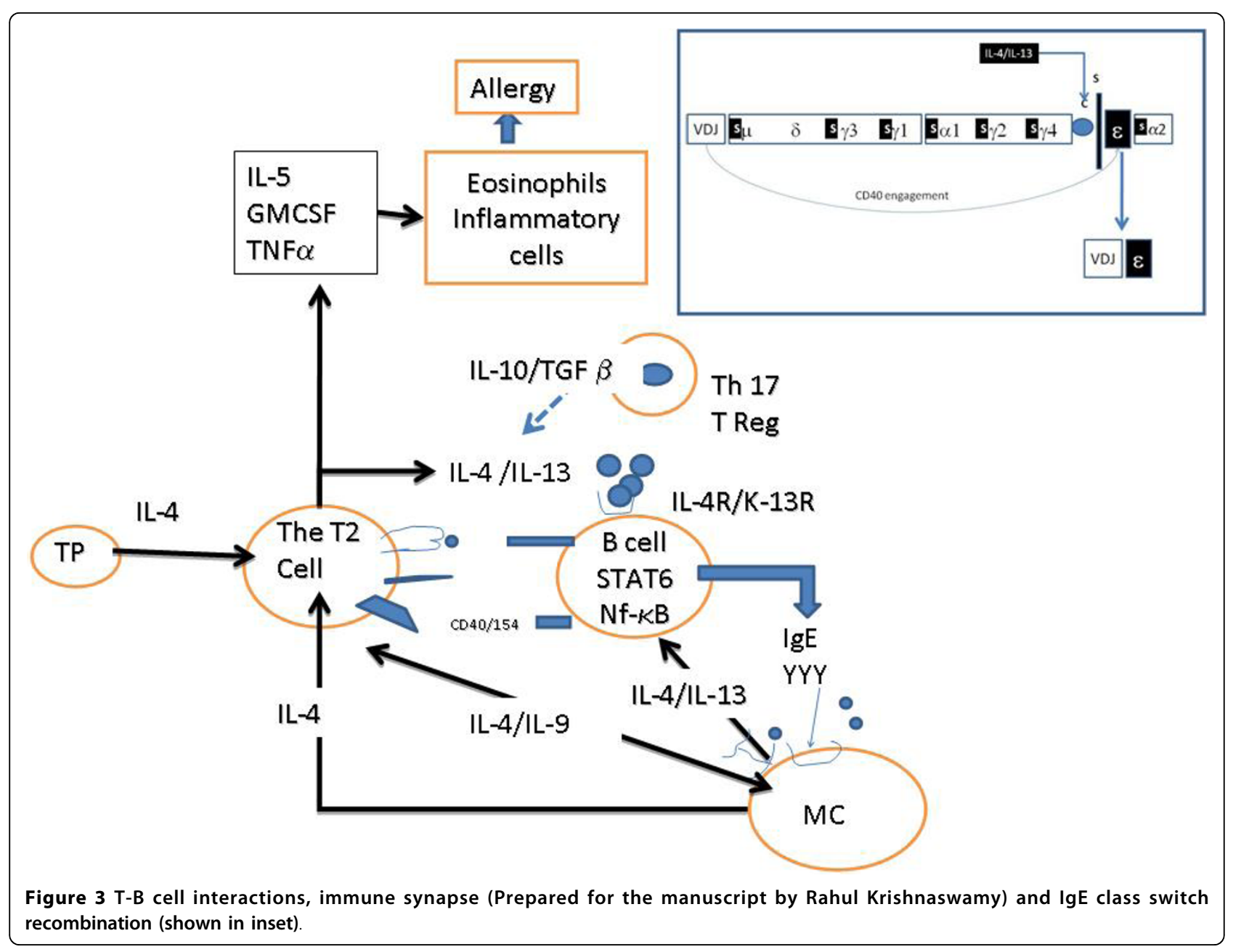




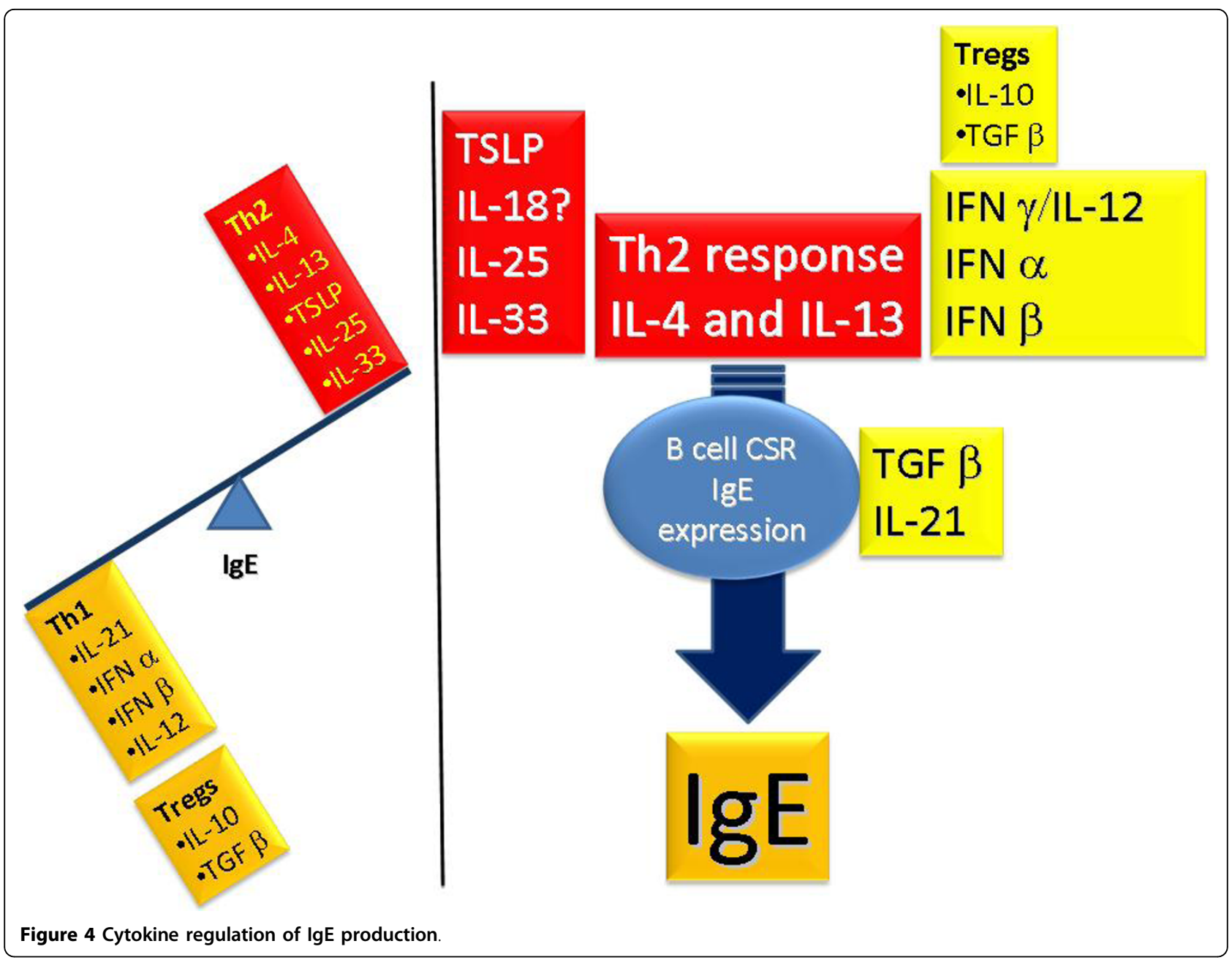

$\mathrm{T}$ regulatory (Treg) cells have important influences on the regulation of IgE synthesis. In the presence of specific growth factors and cytokines, $\mathrm{T}$ cell precursors can develop into Th1, Th2, Th17 and Treg cells (Figure 5). Th2 cells, regulated by GATA3 and STAT6 transcription factors, enhance IgE CSR (IL-4 and IL-13) and synthesis, while Th1 cells, regulated by $\mathrm{T}$-bet and STAT4, inhibit the Th2-IgE axis. T cells with regulatory function include traditional Treg cells, Th3 cells (expressing TGF $\beta$ ) and Tr1 cells (peripherally-derived Treg cells expressing IL-10). These cells have negative regulatory effects on IgE synthesis. Tregs express CD25 and FOXP3 transcription factor and are thymicallyderived. They develop from CD4+ precursor cells in the presence of retinoic acid (RA), TGF $\beta$ and IL-2. By expressing TGF $\beta$ and IL-10, Tregs inhibit IgE CSR and synthesis.

\section{Ige Dysregulation}

Normal levels of IgE are highly variable in the population. Factors regulating IgE levels include age, gene-by- environment interactions, genetic factors (such as certain polymorphisms), racial factors (higher levels are seen in African Americans and persons of Filipino descent), sex (males tending to have higher levels) and season (IgE levels may increase during pollen season in allergic individuals).

\section{Immune Dysregulation Associated with IGE Deficiency}

IgE hypogammaglobulinemia is currently defined as a significant decrease in serum levels of $\operatorname{IgE}(<2.5 \mathrm{IU} / \mathrm{mL})$ in a patient whose other immunoglobulin levels are normal (selective IgE deficiency) or diminished (mixed IgE deficiency). It is a laboratory finding that does not necessarily equate to a clinical disorder.

The prevalence of IgE deficiency is highly dependent on the population under study. The authors measured serum IgE levels in 500 Red Cross (RC) blood donors, 974 allergy-immunology (AIC) patients, and 155 rheumatology practice (RP) patients, and found that $2.6 \%$, $8.1 \%$, and $9.7 \%$ of these subjects, respectively, had 


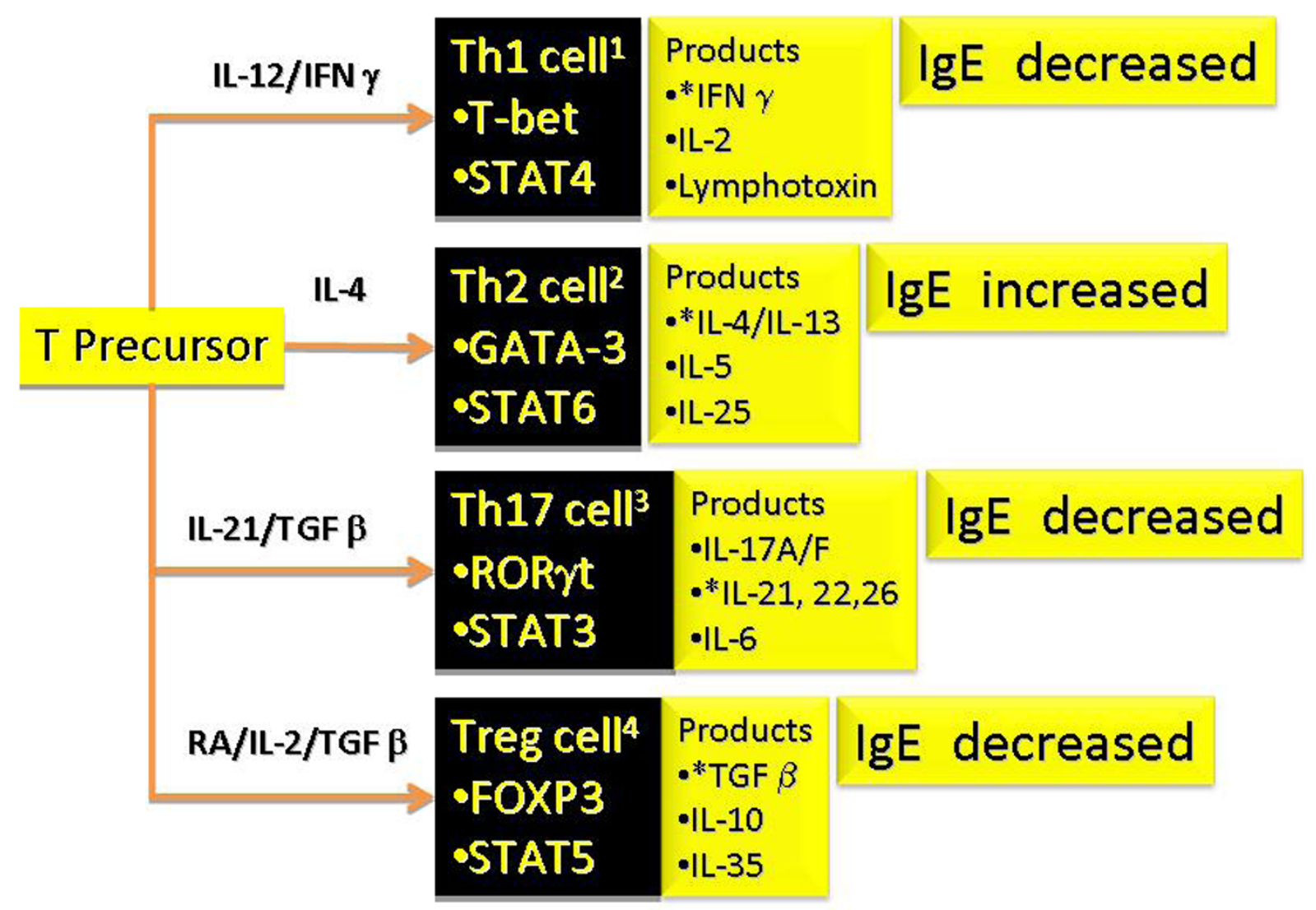

*= autocrine factors- factors expressed by cell type that enhances function of the same cell type $1=$ Suppressed in diseases with high IgE such as HIES and atopy

$2=$ Increased in atopy, parasitic disease, HIES etc

$3=$ Decreased in HIES

4=Decreased in atopy, WAS, IPEX, Omenn syndrome

Figure $5 \mathrm{~T}$ cell subsets that have effects on IgE (Refer to text for more details).

undetectable levels of IgE. IgE deficiency was selective in $0.8 \%$ of RC donors, $3.1 \%$ of AIC patients, and $1.3 \%$ of RP patients, and mixed in $1.8 \%, 5.0 \%$ and $8.4 \%$ of these cohorts, respectively. Associated immunoglobulin deficiencies also varied with the population under study (Table 2). Low serum levels of IgE can also accompany other immunologic deficiency diseases, including common variable immunodeficiency, IgG subclass deficiencies, ataxia telangiectasia, and Bruton's hypogammaglobulinemia [10,11].
Biological Significance

Prevention and control of infection

Several early reports suggested that isolated deficiencies in IgE predisposed to chronic sinopulmonary disease $[12,13]$, whereas others found no such association $[10,14]$. At the time, there was no standard methodology in use for measuring IgE levels, nor did the authors of the reports use a common definition of what constitutes a true deficiency in this immunoglobulin. However, more recent reports using standardized technologies

Table 2 Prevalence of IgE Hypogammaglobulinemia

\begin{tabular}{ccccc}
\hline & Selective deficiency & Mixed deficiency & Total & Common associated deficiencies* \\
\hline AIC patients $(\mathrm{N}=974)$ & $3.1 \%$ & $5.0 \%$ & $8.1 \%$ & $\operatorname{lgG} 4, \operatorname{lgG} 1, \operatorname{lgG} 2 \& \operatorname{lgG} 3$ \\
\hline RP patients $(\mathrm{N}=155)$ & $1.3 \%$ & $8.4 \%$ & $9.7 \%$ & $\lg \mathrm{2}, \lg A 1, \operatorname{lgG} 2, \operatorname{lgG} 4$ \\
\hline RC donors $(\mathrm{N}=500)$ & $0.8 \%$ & $1.8 \%$ & $2.6 \%$ & $\operatorname{lgG} 4$ \\
\hline
\end{tabular}

*In descending order of frequency 
indicate that IgE antibody may play a protective role in some parasitic, bacterial, and viral infections in humans [15-19], and possess anti-tumor properties in vitro $[20,21]$.

Secord and associates reported that the incidence of opportunistic infection and failure to thrive was lower in children with HIV-1 infection and high IgE levels than it was in HIV-1 infected children with low or normal IgE levels and similar decreases in CD4+ $\mathrm{T}$ lymphocyte counts; IgE anti-HIV antibody was detected in $43 \%$ of the children with high IgE levels[14]. Pellegrino and associates found that all members of a group of long-term pediatric survivors with maternally transmitted HIV infection had elevated total serum IgE levels and made anti-HIV-1 IgE capable of inhibiting HIV replication in vitro; the inhibitory effect was reversed when IgE was removed using immunoaffinity columns or anti-IgE antibody[15].

In a study involving 700 asymptomatic subjects from Tanzania, Bereczky and associates found that high IgE (but not IgG) anti-P. falciparum antibody was associated with a reduced risk for subsequent development of clinically evident malaria [16]. Duarte et al also found that $P$. falciparum-specific IgE responses contributed to the control of malaria, particularly in asymptomatic individuals [17]. There are also reports that IgE antibody can provide immunity against $B$. burgdorferi infection in children that lasts throughout adulthood [18], and contribute to the expulsion of intestinal parasites such as $N$. americanus [19]. The authors have found that IgE deficiency predisposes to sinopulmonary infection with common respiratory pathogens, including Streptococcus pneumoniae, Haemophilus influenzae, and Moraxella catarrhalis in patients of their allergy-immunology clinic [22].

\section{Protection against autoimmune disease}

The prevalence of autoimmune disease is recognized to be increased in persons with immunoglobulin deficiencies - particularly those with IgA hypogammaglobulinemia [23]. The authors have documented a similar predisposition in AIC patients with deficiencies in IgE [22]. There are potentially a number of mechanisms that could explain this association (Figure 6).

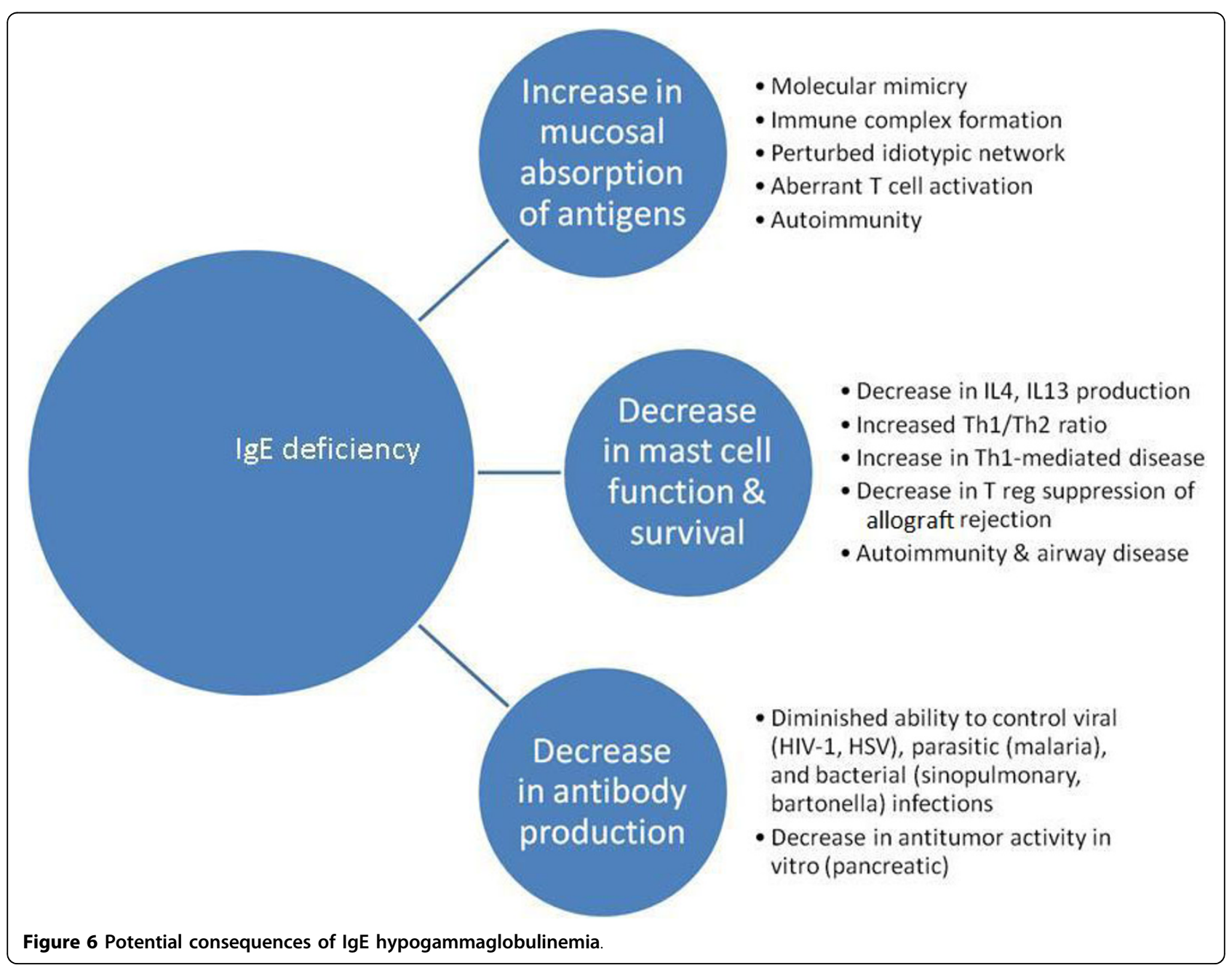


IgE is predominantly a mucosal immunoglobulin. Hence, as is postulated with IgA, it is possible that IgE protects against autoimmunization by preventing the systemic absorption of mucosal antigens [23]. A lack of antigen exclusion at the mucosal barrier could allow exogenous antigens to induce autoimmune responses by stimulating autoreactive lymphocytes through molecular mimicry $[24,25]$; by promoting immune complex formation [26]; by super-antigen-induced polyclonal activation of lymphocytes [27]; by inducing a perturbation of the idiotypic network [28]; and/or by aberrant induction of MHC class II antigens [29].

Evidence also indicates that rather than merely priming mast cells to respond to specific antigen, IgE, in the absence of cross-linking agents, favorably influences mast cell survival, receptor expression, and mediator release, and hence, has an important and active role in facilitating immune responses [30]. Mast cells have been shown to be essential intermediaries in Treg induced allograft tolerance in mice [31]; it is possible, therefore, that IgE deficiency predisposes to autoimmunity by adversely effecting mast cell survival and function. It is also possible that common genetic factors predispose an individual to both IgE deficiency and autoimmune disease, or that low levels of IgE merely reflect an imbalance between Th1 and Th2 lymphocyte activity. That, in turn, favors the development of Th1-mediated autoimmune diseases such as systemic lupus erythematosus and rheumatoid arthritis [32,33]. Systemic lupus erythematosus also may be related to Treg dysregulation, auto-antibody or anti-apoptotic defect.

\section{Protection against reactive airway disease}

The authors found that the prevalence of non-allergic reactive airway disease (rhinosinusitis, bronchitis and asthma) was increased in AIC patients with IgE deficiency. However, it was unclear as to whether these findings were the result of IgE deficiency or reflected selection bias inherent in allergy practices. In a study involving 664 pregnant women, Levin and associates found that the 21 individuals with low serum $\operatorname{IgE}(<2.0$ $\mathrm{IU} / \mathrm{mL}$ ) had a higher prevalence of symptoms of rhinosinusitis, but a lower prevalence of physician diagnosed rhinosinusitis when compared to those with normal to elevated IgE levels [33]. Other studies on the prevalence of airway disease in IgE deficient patients are likewise inconclusive $[10,12,34]$. Experimental evidence is emerging that may provide an explanation for the occurrence of non-infectious, non-allergic airway inflammation in some IgE deficient patients. Kang and associates have demonstrated the occurrence of airway inflammation in lymphotoxin-deficient $\alpha$ (LT $\alpha-/-)$ mice, accompanied by diminished levels of IgE and reduced airway responsiveness, to both environmental and induced antigen challenge [35]. The lung inflammation in the LT $\alpha-/$ - mice is Th1-mediated and alleviated by reconstitution with IgE. Depletion of IgE in wild-type mice duplicates the lung pathologies of the LT $\alpha-/$ - mice, which is also reversed by the administration of IgE. The authors of this article suggest that the presence of low levels of IgE impairs the ability of mast cells to respond normally to airway antigens and, consequently, to produce cytokines that favor Th2 development (IL-4, IL-13); Th1 responses to the uncleared antigens then predominate.

\section{Clinical Features}

In our experience, the majority of IgE deficient patients seek medical advice because of persistent sinorespiratory symptoms that are often assumed to be allergic in origin [22]. In our own Allergy Immunology clinic population, $79 \mathrm{IgE}$ deficient patients have been identified. All of these patients tested negative on skin testing or in vitro allergy testing to a wide spectrum of indoor and outdoor allergens. When compared to a sex and aged-matched control group from the same clinic with normal levels of IgE, these subjects were more likely to complain of arthralgias, chronic fatigue, and symptoms suggestive of airway infection. In addition, they had a significantly higher prevalence of autoimmune disease and, as previously noted, non-allergic reactive airway disease. Sixtytwo percent of the IgE deficient patients had depressed levels of other immunoglobulins, most commonly IgG4; 38 percent had selective IgE deficiencies. Not unexpectedly, serious infection involving both the upper and lower respiratory tract was more common in patients with low IgE and concomitant deficiencies in other immunoglobulins. Thus, in our experience, patients with IgE deficiency have a higher prevalence of sinopulmonary disease, chronic fatigue, arthralgias, autoimmune disease, and concomitant immunoglobulin deficiencies.

At the present time, attempts to replace IgE in persons with IgE hypogammaglobulinemia are neither feasible nor recommended. Rather, IgE deficient patients should be given standard therapy for their underlying conditions.

\section{Immune Dysregulation Associated with High IGE Levels \\ Atopic Disease}

Elevated levels of IgE may be seen in atopic disease, with the caveat that normal levels of IgE do not exclude atopy. Very high levels of IgE may be found in patients with food allergy, allergic fungal disease (such as sinobronchial airway mycoses or allergic fungal sinusitis) and atopic eczema. Table 3 lists conditions associated with elevated IgE levels, while Table 4 lists conditions with very high IgE levels and approaches to their evaluation. 
Table 3 Elevated IgE: Etiologies and Evaluation

\begin{tabular}{|c|c|c|c|}
\hline Main category & Sub-Category & Examples & Diagnosis \\
\hline \multirow[t]{4}{*}{ Atopy } & Respiratory & Rhinitis, asthma, SAM & ST/RAST, PFT, Chest CT scan \\
\hline & Food allergy & Peanut/shrimp allergy & Food ST/RAST, Challenge \\
\hline & Dermatological & Eczema, urticaria & RAST/Patch, biopsy, culture \\
\hline & Other & Allergic Fungal Sinusitis & ST/RAST/Sinus imaging \\
\hline \multirow[t]{4}{*}{ Immune Deficiency } & Mixed $T$ and $B$ & Omenn syndrome & Flow, Immune tests \\
\hline & Syndromic & DiGeorge, WAS, HIES & Genetic, platelet, clinical \\
\hline & Dysregulation & IPEX & Treg cell studies \\
\hline & Humoral & Selective IgA deficiency & IgA level, functional antibody \\
\hline \multirow[t]{4}{*}{ Infection } & Bacterial & Pertussis, S. Aureus & Cultures, serology, clinical \\
\hline & Fungal & Aspergillus, Candida & Cultures, biopsy, serology \\
\hline & Viral & EBV, CMV, HIV & Serology, PCR, cultures \\
\hline & Mycobacteria & Leprosy, TB & Clinical, biopsy, culture \\
\hline \multirow[t]{2}{*}{ Parasitic infestation } & Helminth & Strongyloid, others & Clinical, serology, stool exam \\
\hline & Protozoan & Malaria & Clinical, blood smear \\
\hline \multirow[t]{2}{*}{ Malignancy } & Hematological & Myeloma, Lymphoma & SPEP***, Bone marrow \\
\hline & Solid tumor & Lung/colon/Breast & Radiology, biopsy \\
\hline \multirow[t]{2}{*}{ Inflammatory } & Vasculitides & Kawasaki, PAN* CSS** & ANCA, biopsy \\
\hline & Inflammatory Arthritis & Rheumatoid arthritis & Rheumatoid factor, $C C P^{* * * *}$ \\
\hline \multirow[t]{2}{*}{ Dermatological } & Blistering disease & Bullous pemphigoid & Biopsy, antibody \\
\hline & Idiopathic & Alopecia areata & Clinical, biopsy \\
\hline \multirow[t]{3}{*}{ Systemic disease } & Renal & Nephrotic syndrome & Urine protein, biopsy \\
\hline & Intoxication & Medications, alcohol & History, toxicology \\
\hline & Pulmonary & Cystic fibrosis & CFTR Mutation, sweat chloride \\
\hline Others & Miscellaneous & RA, burns, Nicotine & Serology, history etc \\
\hline
\end{tabular}

* PAN - Polyarteritis nodasa, ${ }^{* *}$ CSS - Churg-Strauss Syndrome, ${ }^{* *}$ SPEP - serum protein electrophoresis,

${ }^{* * * *} \mathrm{CCP}-$ cyclic citrullinated peptide

Table 4 Conditions with very high IgE levels

\begin{tabular}{ll}
\hline Extreme IgE Elevation & \\
\hline Allergic fungal disease & Lympho-reticular Malignancy \\
HIV infection & Parasitic Disease \\
Atopic Dermatitis and Food Allergy & Netherton Syndrome \\
Hyper-IgE syndrome & IgE Myeloma \\
\hline
\end{tabular}

\section{Immune Deficiency Disease}

Several immune deficiency disorders are associated with allergic manifestations. These include selective IgA deficiency and Common Variable Immunodeficiency. In addition, several primary immune deficiency disorders may demonstrate very high IgE levels[36]. These include Hyper-IgE syndromes (HIES), Immunodysregulation, polyendocrinopathy, enteropathy, X-linked syndrome (IPEX), The Wiskott-Aldrich Syndrome (WAS), Omenn syndrome and some forms of DiGeorge syndrome. Hyper-IgE syndrome [37-40] is characterized by highly elevated IgE levels, skin disease and repeated infections. IgE levels tend to exceed $10,000 \mathrm{U} / \mathrm{mL}$, although a huge variability in levels may be observed. HIES syndrome can be idiopathic, autosomal dominant (AD) or autosomal recessive (AR). Most cases appear to have a sporadic basis, but mutations in the STAT3 gene is a feature of the autosomal dominant disorder (also referred to as type 1). AD HIES is characterized by typical skeletal changes such as "coarse facies", abnormal dentition and infection (Staphylococcal pneumonia and/or a pneumatocele). In AR HIES (also known as type 2), recurrent pneumonias, severe viral infections (Molluscum, Herpes simplex), neurological disease and vasculitis may be presenting features and mutations in the TYK2 gene may be seen.

IPEX is a rare syndrome mediated by a reduced or absent Treg population [36,41]. The syndrome manifests as early-onset enteritis (diarrhea), endocrinopathy (type 1 diabetes or hypothyroidism), elevated IgE levels and dermatitis/eczema. Hematological dyscrazias such as anemia, thrombocytopenia and eosinophilia are also observed. IPEX is secondary to mutations of the FOXP3 gene and a resultant deficiency of Treg cells. An increased Th2 response and elevated IgE levels are observed.

Wiskott-Aldrich syndrome is an X-linked disorder characterized by current infection, thrombocytopenia (with small platelets), neutropenia, eczema, high IgE levels, a very high prevalence of autoimmunity (including arthropathy, vasculitis, and inflammatory bowel disease) and malignancy. The defect lies in the WAS protein (or WASP) that is crucial to $\mathrm{T}$ cell, platelet and neutrophil function. 
Omenn syndrome is a rare disorder presenting with recurrent infection, diarrhea, alopecia, eczema/erythroderma, lymphadenopathy, hepatosplenomegaly, eosinophilia and elevated IgE levels. Immune assessment shows elevated IgE levels in spite of deficiency in B cells numbers, panhypogammaglobulinemia, oligoclonal, nonfunctional $\mathrm{T}$ cell expansion and excessive Th2 skewing. The patients demonstrate one of several defects: mutations in RAG genes, Artemis gene, IL-7 receptor encoding gene and the RMRP gene (RNA component of mitochondrial RNA-processing endoribonuclease).

A subgroup of patients with DiGeorge syndrome may present not only with the profound $\mathrm{T}$ cell defect, seen with thymic aplasia, but also with findings consistent with Omenn syndrome (including elevated IgE levels and eosinophilia).

\section{Systemic Infections}

Elevated IgE levels have been described in a variety of bacterial, fungal, mycobacterial and viral infections (listed in Table 4). Leprosy [42] and tuberculosis [43] have rarely been associated with elevated IgE levels $[44,45]$. Elevated IgE levels have also been described in viral infections (Epstein-Barr Virus and Cytomegalovirus). HIV infection is a well-recognized cause for elevated IgE levels [46-48]. Elevated IgE levels have been described in both adults and in children infected with HIV-1 [49], and are associated with a poorer prognosis [50]. A hyper-IgE-like syndrome and severe eczema have also been described with advanced HIV-1 infection [51].

\section{Parasitic Disease}

Ascaris [52], Capillariasis [53], Paragonimiasis [54], Fasciola hepatica [55,56], Schistosomiasis [57,58], Hookworm (Trichuriasis) [59], Echinococcus [60], Onchocercariasis [61] and Malaria [62] have all been associated with elevated IgE levels. Of the many parasitic disorders, only a few are directly relevant to North American and these will be reviewed below. Giardiasis, Strongyloidiasis, Trichinella spiralis and Toxocara species occur with some frequency and have certain distinct and unique presentations.

Strongyloidiasis and its systemic consequences were reviewed by the authors recently [63]. Infection with $S$. stercoralis occurs when the skin of the feet contact freeliving filariform larvae in the soil. The filariform larvae penetrate the skin and invade the blood vessels and subsequently enter the alveoli of the lung, where they are coughed up, swallowed and undergo maturation in the duodenum and jejunum. Over half the patients who harbor $S$. stercoralis have symptoms are related to the GI tract invasion, lung invasion or dissemination with strongyloid hyperinfection. The latter, usually seen in patients treated with glucocorticoids or immunosuppressive agents, can be fatal with complications such as sepsis, gram negative meningitis and/or respiratory distress $[64,65]$. Treatment with ivermectin $(200 \mu \mathrm{g} / \mathrm{Kg} /$ day $)$ is associated with a $90 \%$ cure rate.

Toxocariasis is a well recognized zoonotic disease mediated by the nematode belonging to the genus Toxocara. Adult worms are present in the intestinal tracts of dogs (T. canis) or cats (T. cati) and human infection is caused by egg ingestion $[66,67]$. Infective larvae migrate through the liver and lung and result in a plethora of allergic and inflammatory manifestations, referred to as visceral, ocular or cutaneous larva migrans. Eosinophilia, elevated IgE and involvement of brain, muscle, liver and lungs are responsible for the clinical manifestations. Treatment with albendazole or mebendazole and diethylcarbamazine may be attempted.

Trichinellosis is mediated by the nematode, Trichinella spiralis, transmitted by eating undercooked pork or larval forms present in cyst form in striated muscle [68]. Many patients may remain asymptomatic, while some patients develop abdominal pain, diarrhea, fever and excruciating myalgia (calf or masseter muscle). During the invasive stage of the illness, allergic phenomena such as urticaria or periorbital angioedema may occur. The disease is treated with albendazole and some studies have suggested a beneficial effect for glucocorticoids during the allergic and inflammatory stages of the disease.

Giardia lamblia is a protozoan parasite that infects humans following the ingestion of infectious cysts (fecal-oral route or from contaminated food or well water). Symptoms include abdominal cramps, bloating, watery diarrhea and malabsorption. Elevated IgE levels and eosinophilia have been described [69]. Treatment with metronidazole, tinidazole, nitazoxanide or paramomycin may be variably effective, with paramomycin reserved for infected pregnant women.

\section{Neoplasia}

A variety of neoplastic and hematological disorders have been associated with IgE.

Solid tumors such as cancers of the lung, colon, prostate and breast have been reported to elevate IgE levels [70]. These may be the result of dysregulation of the Th1/Th2-IgE axis [71]. Other neoplastic conditions known to present with elevated IgE levels include IgE myeloma and malignant lymphoma. Eosinophilia and elevated IL-4 and IgE levels have been shown in both Hodgkin's disease (serum IgE as well as intracellular IgE within Reed-Sternberg cells) and malignant/non-Hodgkin's lymphoma [72]. In multiple myeloma, polyclonal elevation of $\operatorname{IgE}$ is associated with improved survival [73]. 
IgE myeloma was first described in 1967 as an "atypical myeloma immunoglobulin" and since then several other cases of this rare myeloma have been reported [74]. The presentation of IgE myeloma is similar to that of an IgG myeloma, and most patients are diagnosed between the $6^{\text {th }}$ and $7^{\text {th }}$ decades of life.

\section{Inflammatory Disorders}

Many other inflammatory disorders have been associated with elevated IgE levels. These include Kawasaki syndrome [75], vasculitides such as polyarteritis nodosa or Churg-Strauss syndrome[76], Guillian-Barre syndrome [77,78], inflammatory neuropathies [79], burns [80,81], Sjogren's syndrome [82], certain patients with rheumatoid arthritis who may also develop IgE rheumatoid factors [83], graft-versus-host disease and bone marrow transplantation [84] and scleroderma-like syndromes [85]. The prognostic or diagnostic role for IgE in these disorders is unknown

\section{Dermatological Disorders}

Several dermatological and inflammatory disorders have been associated with IgE dysregulation and elevated IgE levels. Alopecia areata $[86,87]$, erythema nodosum (especially due to streptococcus)[88], acral dermatitides and blistering diseases, such as pemphigus, have been associated with IgE elevation $[89,90]$.

\section{Systemic and Toxic Disorders}

Alcohol ingestion has been associated with elevated IgE levels [91]. Certain forms of nephritides demonstrate IgE elevation [92]. The elevation of IgE in these disorders may be due to dysregulation of the IL-4-IL-13 axis. In idiopathic nephritic syndrome, IL-13 levels are elevated, while in minimal change disease, polymorphisms of the IL-4 gene have been described [93]. Other conditions reported to show elevated IgE levels include cystic fibrosis [94] (with associated ABPA-like disease, probably secondary to increased airway penetration by allergen), nicotine abuse [95] and pulmonary hemosiderosis (Heiner's syndrome)[96].

\section{Conclusion}

Major advancements have been made in our understanding of the molecular basis of IgE class switching including roles for $\mathrm{T}$ cells, cytokines and $\mathrm{T}$ regulatory cells in this process. Dysregulation of this process may result in either elevated IgE levels or IgE deficiency. Evaluation of a patient with elevated IgE must involve a detailed differential diagnosis and consideration of various immunological and non-immunological disorders. The use of appropriate tests will allow the correct diagnosis to be made. This can often assist in the development of tailored treatments.

\section{Author details}

${ }^{1}$ Division of Allergy and Immunology, Quillen College of Medicine, East Tennessee State University, Johnson City, TN 37614, USA. ²Department of Medicine, Quillen College of Medicine, East Tennessee State University, Johnson City, TN 37614, USA. ${ }^{3}$ James H. Quillen VA Medical Center, Mountain Home, TN, USA

\section{Authors' contributions}

MP carried out some literature search, partially drafted the manuscript, and proofread the final version. JKS helped to draft the IgE deficiency aspect of the manuscript. DSC helped to draft the manuscript, revised it for important intellectual content, and assisted the finalizing of the manuscript. GK conceived and managed the study, drafted the manuscript, managed references, generated figures and tables, and has given final approval of the version to be published. All authors have read and approved the final manuscript.

\section{Competing interests}

The authors declare that they have no competing interests.

Received: 21 December 2009 Accepted: 23 February 2010 Published: 23 February 2010

\section{References}

1. Williams AF, Barclay AN: The immunoglobulin superfamily-domains for cell surface recognition. Annu Rev Immunol 1988, 6:381-405.

2. Krishnaswamy G, Hall K, Youngberg G, Hossler F, Johnson D, Block WA, Huang SK, Kelley J, Chi DS: Regulation of eosinophil-active cytokine production from human cord blood-derived mast cells. J Interferon Cytokine Res 2002, 22:379-388.

3. Chi DS, Fitzgerald SM, Krishnaswamy G: Mast cell histamine and cytokine assays. Methods Mol Biol 2006, 315:203-215.

4. Krishnaswamy G, Ajitawi O, Chi DS: The human mast cell: an overview. Methods Mol Biol 2006, 315:13-34

5. Lee SA, Fitzgerald SM, Huang SK, Li C, Chi DS, Milhorn DM, Krishnaswamy G: Molecular regulation of interleukin-13 and monocyte chemoattractant protein-1 expression in human mast cells by interleukin-1beta. Am J Respir Cell Mol Biol 2004, 31:283-291.

6. Shakoory B, Fitzgerald SM, Lee SA, Chi DS, Krishnaswamy G: The role of human mast cell-derived cytokines in eosinophil biology. J Interferon Cytokine Res 2004, 24:271-281.

7. Geha RS, Jabara HH, Brodeur SR: The regulation of immunoglobulin $\mathrm{E}$ class-switch recombination. Nat Rev Immunol 2003, 3:721-732.

8. de Vries JE, Punnonen J, Cocks BG, de Waal MR, Aversa G: Regulation of the human IgE response by IL4 and IL13. Res Immunol 1993, 144:597-601.

9. Marsh DG, Neely JD, Breazeale DR, Ghosh B, Freidhoff LR, Ehrlich-Kautzky E, Schou C, Krishnaswamy G, Beaty TH: Linkage analysis of IL4 and other chromosome 5q31.1 markers and total serum immunoglobulin $\mathrm{E}$ concentrations. Science 1994, 264:1152-1156.

10. Polmar SH, Waldmann TA, Balestra ST, Jost MC, Terry WD: Immunoglobulin $E$ in immunologic deficiency diseases. I. Relation of $\lg E$ and $\lg A$ to respiratory tract disease in isolated IgE deficiency, IgA deficiency, and ataxia telangiectasia. J Clin Invest 1972, 51:326-330.

11. Waldmann TA, Polmar SH, Balestra ST, Jost MC, Bruce RM, Terry WD: Immunoglobulin E in immunologic deficiency diseases. II. Serum IgE concentration of patients with acquired hypogammaglobulinemia, thymoma and hypogammaglobulinemia, myotonic dystrophy, intestinal lymphangiectasia and Wiskott-Aldrich syndrome. J Immunol 1972, 109:304-310.

12. Ammann AJ, Roth J, Hong R: Recurrent sinopulmonary infections, mental retardation, and combined IgA and IgE deficiency. J Pediatr 1970, 77:802-804.

13. Schoettler JJ, Schleissner LA, Heiner DC: Familial IgE deficiency associated with sinopulmonary disease. Chest 1989, 96:516-521.

14. Secord EA, Kleiner GI, Auci DL, Smith-Norowitz T, Chice S, Finkielstein A, Nowakowski M, Fikrig S, Durkin HG: IgE against HIV proteins in clinically healthy children with HIV disease. J Allergy Clin Immunol 1996, 98:979-984.

15. Pellegrino MG, Bluth MH, Smith-Norowitz T, Fikrig S, Volsky DJ, Moallem H, Auci DL, Nowakowski M, Durkin HG: HIV type 1-specific lgE in serum of long-term surviving children inhibits HIV type 1 production in vitro. AIDS Res Hum Retroviruses 2002, 18:363-372. 
16. Bereczky S, Montgomery SM, Troye-Blomberg M, Rooth I, Shaw MA, Farnert A: Elevated anti-malarial lgE in asymptomatic individuals is associated with reduced risk for subsequent clinical malaria. Int $J$ Parasitol 2004, 34:935-942.

17. Duarte J, Deshpande P, Guiyedi V, Mecheri S, Fesel C, Cazenave PA Mishra GC, Kombila M, Pied S: Total and functional parasite specific lgE responses in Plasmodium falciparum-infected patients exhibiting different clinical status. Malar J 2007, 6:1.

18. Bluth MH, Robin J, Ruditsky M, Norowitz KB, Chice S, Pytlak E, Nowakowski M, Durkin HG, Smith-Norowitz TA: IgE anti-Borrelia burgdorferi components (p18, p31, p34, p41, p45, p60) and increased blood CD8+CD60+ T cells in children with Lyme disease. Scand J Immunol 2007, 65:376-382.

19. Pritchard $\mathrm{DI}$, Walsh EA: The specificity of the human lgE response to Necator americanus. Parasite Immunol 1995, 17:605-607.

20. Reali E, Greiner JW, Corti A, Gould HJ, Bottazzoli F, Paganelli G, Schlom J, Siccardi AG: IgEs targeted on tumor cells: therapeutic activity and potential in the design of tumor vaccines. Cancer Res 2001, 61:5517-5522.

21. Fu SL, Pierre J, Smith-Norowitz TA, Hagler M, Bowne W, Pincus MR, Mueller CM, Zenilman ME, Bluth MH: Immunoglobulin E antibodies from pancreatic cancer patients mediate antibody-dependent cell-mediated cytotoxicity against pancreatic cancer cells. Clin Exp Immunol 2008, 153:401-409.

22. Smith JK, Krishnaswamy GH, Dykes R, Reynolds S, Berk SL: Clinical manifestations of IgE hypogammaglobulinemia. Ann Allergy Asthma Immunol 1997, 78:313-318.

23. Liblau RS, Bach JF: Selective IgA deficiency and autoimmunity. Int Arch Allergy Immunol 1992, 99:16-27.

24. Oldstone MB: Molecular mimicry and immune-mediated diseases. FASEB $J$ 1998, 12:1255-1265.

25. Oldstone MB: Molecular mimicry, microbial infection, and autoimmune disease: evolution of the concept. Curr Top Microbiol Immunol 2005, 296:1-17.

26. Cunningham-Rundles C, Brandeis WE, Pudifin DJ, Day NK, Good RA Autoimmunity in selective IgA deficiency: relationship to anti-bovine protein antibodies, circulating immune complexes and clinical disease. Clin Exp Immunol 1981, 45:299-304.

27. Paliard X, West SG, Lafferty JA, Clements JR, Kappler JW, Marrack $P$, Kotzin BL: Evidence for the effects of a superantigen in rheumatoid arthritis. Science 1991, 253:325-329.

28. Cooke A, Lydyard PM, Roitt IM: Autoimmunity and idiotypes. Lancet 1984 2:723-725.

29. Sarvetnick N, Liggitt D, Pitts SL, Hansen SE, Stewart TA: Insulin-dependent diabetes mellitus induced in transgenic mice by ectopic expression of class II MHC and interferon-gamma. Cell 1988, 52:773-782.

30. Kitaura J, Song J, Tsai M, Asai K, Maeda-Yamamoto M, Mocsai A, Kawakami Y, Liu FT, Lowell CA, Barisas BG, Galli SJ, Kawakami T: Evidence that IgE molecules mediate a spectrum of effects on mast cell survival and activation via aggregation of the FcepsilonRI. Proc Natl Acad Sci USA 2003, 100:12911-12916.

31. Lu LF, Lind EF, Gondek DC, Bennett KA, Gleeson MW, Pino-Lagos K, Scott ZA, Coyle AJ, Reed JL, Van SJ, Strom TB, Zheng XX, Noelle RJ: Mast cells are essential intermediaries in regulatory T-cell tolerance. Nature 2006, 442:997-1002.

32. Chan RW, Lai FM, Li EK, Tam LS, Chow KM, Li PK, Szeto CC: Imbalance of Th1/Th2 transcription factors in patients with lupus nephritis. Rheumatology (Oxford) 2006, 45:951-957.

33. Canete JD, Martinez SE, Farres J, Sanmarti R, Blay M, Gomez A, Salvador G, Munoz-Gomez J: Differential Th1/Th2 cytokine patterns in chronic arthritis: interferon gamma is highly expressed in synovium of rheumatoid arthritis compared with seronegative spondyloarthropathies. Ann Rheum Dis 2000, 59:263-268.

34. Levy DA, Chen J: Healthy IgE-deficient person. N Engl J Med 1970, 283:541-542.

35. Kang HS, Blink SE, Chin RK, Lee Y, Kim O, Weinstock J, Waldschmidt T, Conrad D, Chen B, Solway J, Sperling Al, Fu YX: Lymphotoxin is required for maintaining physiological levels of serum IgE that minimizes Th1mediated airway inflammation. J Exp Med 2003, 198:1643-1652.

36. Ozcan E, Notarangelo LD, Geha RS: Primary immune deficiencies with aberrant lgE production. J Allergy Clin Immunol 2008, 122:1054-1062.
37. Ring J, Landthaler M: Hyper-lgE syndromes. Curr Probl Dermatol 1989, 18:79-88.

38. Heimall J, Freeman A, Holland SM: Pathogenesis of Hyper IgE Syndrome Clin Rev Allergy Immunol 2009.

39. Tangye SG, Cook MC, Fulcher DA: Insights into the role of STAT3 in human lymphocyte differentiation as revealed by the hyper-lgE syndrome. J Immunol 2009, 182:21-28.

40. Minegishi $Y$, Karasuyama $H$ : Genetic origins of hyper-lgE syndrome. Curr Allergy Asthma Rep 2008, 8:386-391.

41. Gambineri $E$, Perroni $L$, Passerini $L$, Bianchi $L$, Doglioni $C$, Meschi $F$, Bonfanti R, Sznajer $Y$, Tommasini A, Lawitschka A, Junker A, Dunstheimer D, Heidemann PH, Cazzola G, Cipolli M, Friedrich W, Janic D, Azzi N, Richmond E, Vignola S, Barabino A, Chiumello G, Azzari C, Roncarolo MG, Bacchetta R: Clinical and molecular profile of a new series of patients with immune dysregulation, polyendocrinopathy, enteropathy, X-linked syndrome: inconsistent correlation between forkhead box protein 3 expression and disease severity. J Allergy Clin Immunol 2008, 122:1105-1112.

42. Smith DL, Bahna SL, Gillis TP, Clements BH: Atopy and IgE in patients with leprosy. J Allergy Clin Immunol 1990, 85:795-800.

43. Imai T, Katada H, Mikami R, Nishikawa K, Sawaki M, Ishibashi J, Konoike Y, Sawaki M, Nakano H, Mikasa K: [Serum IgE level in pulmonary tuberculosis. Comparison with other respiratory diseases]. Kekkaku 1984 59:483-490.

44. Ellertsen LK, Wiker HG, Egeberg NT, Hetland G: Allergic sensitisation in tuberculosis and leprosy patients. Int Arch Allergy Immunol 2005 138:217-224.

45. Yong AJ, Grange JM, Tee RD, Beck JS, Bothamley GH, Kemeny DM, Kardjito T: Total and anti-mycobacterial lgE levels in serum from patients with tuberculosis and leprosy. Tubercle 1989, 70:273-279.

46. Marone G, Florio G, Triggiani M, Petraroli A, de PA: Mechanisms of IgE elevation in HIV-1 infection. Crit Rev Immunol 2000, 20:477-496.

47. Mazza DS, Grieco MH, Reddy MM, Meriney D: Serum IgE in patients with human immunodeficiency virus infection. Ann Allergy Asthma Immunol 1995, 74:411-414.

48. Ferrazzi $M$, De Rinaldis ML, Salotti A, Cirelli A: Serum lgE levels in human immunodeficiency virus (HIV)-1 infected patients: correlation between IgE and CD4+ cells. Riv Eur Sci Med Farmacol 1993, 15:67-70.

49. Zar HJ, Latief Z, Hughes J, Hussey G: Serum immunoglobulin E levels in human immunodeficiency virus-infected children with pneumonia. Pediatr Allergy Immunol 2002, 13:328-333.

50. Rancinan C, Morlat P, Chene G, Guez S, Baquey A, Beylot J, Salamon R: IgE serum level: a prognostic marker for AIDS in HIV-infected adults? J Allergy Clin Immunol 1998, 102:329-330.

51. Paganelli R, Scala E, Ansotegui IJ, Mezzaroma I, Pinter E, Ferrara $R$, D'Offizi GP, Aiuti F: Hyper IgE syndrome induced by HIV infection. Immunodeficiency 1993, 4:149-152.

52. Fincham JE, Markus MB, van der ML, Adams VJ, van Stuijvenberg ME, Dhansay MA: Ascaris, co-infection and allergy: the importance of analysis based on immunological variables rather than egg excretion. Trans $R$ Soc Trop Med Hyg 2007, 101:680-682.

53. Rosenberg EB, Whalen GE, Bennich $H$, Johansson SG: Increased circulating $\mathrm{IgE}$ in a new parasitic disease-human intestinal capillariasis. $N$ Engl J Med 1970, 283:1148-1149.

54. Kong Y, Ito A, Yang HJ, Chung YB, Kasuya S, Kobayashi M, Liu YH, Cho SY: Immunoglobulin $\mathrm{G}$ (IgG) subclass and IgE responses in human paragonimiases caused by three different species. Clin Diagn Lab Immunol 1998, 5:474-478

55. Espino AM, Osuna A, Gil R, Hillyer GV: Fasciola hepatica: humoral and cytokine responses to a member of the saposin-like protein family following delivery as a DNA vaccine in mice. Exp Parasitol 2005, 110:374-383.

56. Pfister $K$, Turner $K$, Currie $A$, Hall $E$, Jarrett $E E$ : IgE production in rat fascioliasis. Parasite Immunol 1983, 5:587-593.

57. Jiz M, Friedman JF, Leenstra T, Jarilla B, Pablo A, Langdon G, Pond-Tor S, Wu HW, Manalo D, Olveda R, Acosta L, Kurtis JD: Immunoglobulin E (lgE) responses to paramyosin predict resistance to reinfection with Schistosoma japonicum and are attenuated by IgG4. Infect Immun 2009 77:2051-2058. 
58. Makhlouf LM, Serwah A, bd El-Hamid AD, Hussein EM, Saad RM: INFgamma, IL-5 and IgE profiles in chronic schistosomiasis mansoni Egyptian patients with or without hepatitis C infection. J Egypt SoC Parasitol 2006, 36:177-196.

59. Loukas A, Prociv P: Immune responses in hookworm infections. Clin Microbiol Rev 2001, 14:689-703, table..

60. Khabiri AR, Bagheri F, Assmar M, Siavashi MR: Analysis of specific IgE and IgG subclass antibodies for diagnosis of Echinococcus granulosus. Parasite Immunol 2006, 28:357-362.

61. Abraham D, Leon O, Schnyder-Candrian S, Wang CC, Galioto AM, Kerepesi LA, Lee JJ, Lustigman S: Immunoglobulin E and eosinophildependent protective immunity to larval Onchocerca volvulus in mice immunized with irradiated larvae. Infect Immun 2004, 72:810-817.

62. Duarte J, Deshpande P, Guiyedi V, Mecheri S, Fesel C, Cazenave PA, Mishra GC, Kombila M, Pied S: Total and functional parasite specific IgE responses in Plasmodium falciparum-infected patients exhibiting different clinical status. Malar J 2007, 6:1.

63. Vadlamudi RS, Chi DS, Krishnaswamy G: Intestinal strongyloidiasis and hyperinfection syndrome. Clin Mol Allergy 2006, 4:8.

64. Olsen A, van LL, Marti H, Polderman T, Polman K, Steinmann P, Stothard R, Thybo S, Verweij JJ, Magnussen P: Strongyloidiasis - the most neglected of the neglected tropical diseases? Trans R Soc Trop Med Hyg 2009.

65. Khasawneh F, Sreedhar R, Chundi V: Strongyloides hyperinfection: an unusual cause of respiratory failure. Ann Intern Med 2009, 150:570-571.

66. Gawor J, Borecka A, Dobosz S, Marczynska M, Zarnowska-Prymek H, Trzebicka A, Juszko J: [Toxocariasis in children-difficult clinical problem]. Przegl Epidemiol 2008, 62:407-413.

67. Obwaller A, Jensen-Jarolim E, Auer H, Huber A, Kraft D, Aspock H: Toxocara infestations in humans: symptomatic course of toxocarosis correlates significantly with levels of $\mathrm{lgE} / \mathrm{anti}-\mathrm{lgE}$ immune complexes. Parasite Immunol 1998, 20:311-317.

68. Gottstein B, Pozio E, Nockler K: Epidemiology, diagnosis, treatment, and control of trichinellosis. Clin Microbiol Rev 2009, 22:127-45, Table.

69. Geller M, Geller M, Flaherty DK, Black P, Madruga M: Serum IgE levels in giardiasis. Clin Allergy 1978, 8:69-71

70. Jensen-Jarolim E, Achatz G, Turner MC, Karagiannis S, Legrand F, Capron M, Penichet ML, Rodriguez JA, Siccardi AG, Vangelista L, Riemer AB, Gould H: AllergoOncology: the role of IgE-mediated allergy in cancer. Allergy 2008, 63:1255-1266.

71. Lucey DR, Clerici M, Shearer GM: Type 1 and type 2 cytokine dysregulation in human infectious, neoplastic, and inflammatory diseases. Clin Microbiol Rev 1996, 9:532-562.

72. Hsu SM: IgE in Reed-Sternberg cells. Blood 1992, 80:286-287.

73. Matta GM, Battaglio S, Dibello C, Napoli P, Baldi C, Ciccone G, Coscia M, Boccadoro M, Massaia M: Polyclonal immunoglobulin E levels are correlated with hemoglobin values and overall survival in patients with multiple myeloma. Clin Cancer Res 2007, 13:5348-5354.

74. Lloyd L, Klingberg SL, Kende M, Howell JF, Clague AE: A case of IgE multiple myeloma. Pathology 2003, 35:87-89.

75. Kusakawa S, Heiner DC: Elevated levels of immunoglobulin $E$ in the acute febrile mucocutaneous lymph node syndrome. Pediatr Res 1976, 10:108-111.

76. Krous HF, Clausen CR, Ray CG: Elevated immunoglobulin E in infantile polyarteritis nodosa. J Pediatr 1974, 84:841-845.

77. Huang JT: Serum IgE concentrations in neurological diseases. Ann Allergy 1975, 34:1-6.

78. Roca GA, Palomeque RA, Pastor D, X, Molinero EC, Jimenez GR: [GuillainBarre syndrome: a study of 13 children]. An Esp Pediatr 1993, 39:513-516

79. Horiuchi I, Kawano Y, Yamasaki K, Matsuo H, Minohara M, Nakamura T, Hashiguchi H, Ohyagi Y, Yamada T, Kira J: Heightened IgE response to mite antigens in inflammatory neuropathies. J Neurol Sci 1999, 166:77-80.

80. Polacek V, Jira M, Fara M, Strejcek J, Konigova R: Immunoglobulin E (IgE) in patients with severe burns. Burns Ind Therm Inj 1987, 13:458-461.

81. Elagina LV, Lagvilava MG, Gordeev VF: [Value of determining serum immunoglobulin E in burn patients]. Klin Med (Mosk) 1986, 64:124-126.

82. Azuma N, Katada Y, Harada Y, Arimoto H, Kimura Y, Terada H, Tsujino K, Kida H, Yamamoto S, Kudo E, Umeshita M, Mima T, Saeki Y: [Case of primary Sjogren's syndrome with hypereosinophilia and elevation of serum IgE: measurements of serum IL-4, IL-5 and the IgG subclass]. Arerugi 2005, 54:646-651.
83. Ferreira RA, Ferriani VP, Sopelete MC, Silva DA, Mineo JR, Kiss MH, Silva CH: Immunoglobulin E-rheumatoid factor in juvenile rheumatoid arthritis. Rev Hosp Clin Fac Med Sao Paulo 2002, 57:209-216.

84. Heyd J, Donnenberg AD, Burns WH, Saral R, Santos GW: Immunoglobulin E levels following allogeneic, autologous, and syngeneic bone marrow transplantation: an indirect association between hyperproduction and acute graft-v-host disease in allogeneic BMT. Blood 1988, 72:442-446.

85. Romano C, Sellitto A, De FU, Rossiello R, Rossiello L, Giunta R, Lucivero G: A scleroderma-like cutaneous syndrome associated with a marked Th2type immune response occurring after a prosthetic joint implant. J Clin Rheumatol 2009, 15:133-137.

86. Tokura Y, Sugita K, Kabashima K, Ito T, Yagi H: Alopecia universalis associated with impaired interleukin-4 production and low serum lgE level. J Am Acad Dermatol 2007, 57:S22-S25.

87. Kasumagic-Halilovic E, Prohic A: Serum levels of total immunoglobulin e in patients with alopecia areata: relationship with clinical type of the disease. Acta Dermatovenerol Croat 2006, 14:149-152.

88. Mandalenaki-Lambrou C, Thomaidis T, Benetos S, Ladis B, Matsaniotis N: Immunoglobulin E in erythema nodosum. Arch Dis Child 1976, 51:391-393.

89. Bowszyc-Dmochowska M, Dmochowski M: Immediate hypersensitivity phenomena in bullous pemphigoid: critical concepts. J Med 2002, 33:189-198.

90. Iwata Y, Komura K, Kodera M, Usuda T, Yokoyama Y, Hara T, Muroi E, Ogawa F, Takenaka M, Sato S: Correlation of IgE autoantibody to BP180 with a severe form of bullous pemphigoid. Arch Dermatol 2008, 144:41-48.

91. Gonzalez-Quintela A, Vidal C, Gude F: Alcohol-induced alterations in serum immunoglobulin e (lgE) levels in human subjects. Front Biosci 2002, 7:e234-e244.

92. bdel-Hafez M, Shimada M, Lee PY, Johnson RJ, Garin EH: Idiopathic Nephrotic Syndrome and Atopy: Is There a Common Link? Am J Kidney Dis 2009.

93. Cheung W, Wei CL, Seah CC, Jordan SC, Yap HK: Atopy, serum IgE, and interleukin-13 in steroid-responsive nephrotic syndrome. Pediatr Nephrol 2004, 19:627-632.

94. Latzin P, Hartl D, Regamey N, Frey U, Schoeni MH, Casaulta C: Comparison of serum markers for allergic bronchopulmonary aspergillosis in cystic fibrosis. Eur Respir J 2008, 31:36-42.

95. Cozen W, az-Sanchez D, James GW, Zadnick J, Cockburn MG, Gill PS, Masood R, Hamilton AS, Jyrala M, Mack TM: Th1 and Th2 cytokines and lgE levels in identical twins with varying levels of cigarette consumption. J Clin Immunol 2004, 24:617-622.

96. Moissidis I, Chaidaroon D, Vichyanond P, Bahna SL: Milk-induced pulmonary disease in infants (Heiner syndrome). Pediatr Allergy Immunol 2005, 16:545-552.

doi:10.1186/1476-7961-8-3

Cite this article as: Pate et al:: Regulation and dysregulation of immunoglobulin E: a molecular and clinical perspective. Clinical and Molecular Allergy 2010 8:3.

\section{Submit your next manuscript to BioMed Central and take full advantage of:}

- Convenient online submission

- Thorough peer review

- No space constraints or color figure charges

- Immediate publication on acceptance

- Inclusion in PubMed, CAS, Scopus and Google Scholar

- Research which is freely available for redistribution 